\title{
Justice in the law of Prostitution in Indonesia; Human Rights Perspective
}

\author{
Mulyono Jamal $^{1}$, Sujiat Zubaidi ${ }^{2}$, Rashda Diana ${ }^{3}$, M. Kholid Muslih ${ }^{4}$, M. Lathif ${ }^{5}$, \\ Ria Rahmawati ${ }^{6}$
}

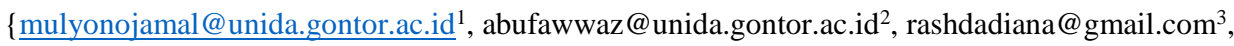
kholidmuslih@unida.gontor.ac.id ${ }^{4}$, ahmadlatief@unida.gontor.ac.id ${ }^{5}$, riarahma@unida.gontor.ac.id $\left.{ }^{6}\right\}$

University of Darussalam Gontor ${ }^{1,2,3,4,5,6}$
\end{abstract}

\begin{abstract}
This study aims to criticize the articles in Indonesian prostitution law so that all parties involved can be trapped by law. This research is library research that is used as content analysis and applies a juridical approach that emphasizes the study of national law and human rights. The article critically revealed that there was a difference in the threat of criminal sanctions for prostitution which were considered unfair because the article on criminal law only ensnared certain parties, not all parties. And this is considered unfair according to the concept of human rights that should be protected by the government. The study argued that the law of prostitution in Indonesia is considered not following the ideology of the nation, especially the first and fifth precepts. It is, therefore, necessary to add wording in the article on criminal law so that all those involved in prostitution can be entangled under the law.
\end{abstract}

Keywords: Laws on prostitution, Human's rights, Criminal sanctions.

\section{Introduction}

Prostitution is a fascinating issue to be discussed primarily in Indonesia which adheres to eastern culture in that it is immoral and considered harmful in society. Prostitution is a social phenomenon carried through selling sexual services as a livelihood by engaging in sexual relations. Kartini Kartono explained that Indonesia's second and third books of the criminal code have no articles that could ensnare commercial sex workers or users of commercial sex services; they only ensnare providers of commercial sex. As a consequence, prostitution occurs because of the absence of a law prohibiting it [1].

There is, therefore, a need to criticize and renew the Criminal Code in the article because it implies injustice among society. There is a need for criticism and renewal of the Criminal Code in the article because of injustices to the applicable law. Law is deemed not to give justice to parties related to prostitution. Whereas every human being has human rights that must be protected by the government, both human rights, social, legal and so on. If only one party is entangled in criminal sanctions because prostitution is very unfair, even though there are differences regarding the legality of prostitution in Indonesia and the West [2].

\section{Research method}

To arrive at the expected research, this study is library research using descriptive methods to describe phenomena related to prostitution that occur in society, especially Indonesia, where prostitution is a crime against decency and how human rights view legal sanctions for the practice of prostitution. The data in this study were obtained from books related to criminal law, Electronic Information and Transaction law, and human rights law, articles, journals relating to prostitution.[3]

This study uses a juridical approach with content analysis in articles 296 and 506 of the Criminal Code, the law no 39 of 1999 concerning human rights and article 27 paragraph 1 of 2008 concerning the Information and Electronic Transactions law. The juridical approach is applied to describe how prostitution is seen from a human rights perspective and Pancasila which is the ideology of the country. Also through this approach, the article would 
discuss whether prostitution is a protected profession according to human rights or a profession that is considered a crime against morality. It too seeks to analyze how the legal sanctions for prostitution have been implemented in Indonesia.

\section{Research results}

Prostitution is a profession protected by the Universal Declaration of Human Rights, especially in the right to work as an integral part of economic, social and cultural rights as stipulated in Articles 22-27 [4]. The Western conception of human rights has designed prostitution as localization. The aim of localization of prostitution is so that commercial sex workers can be monitored for their condition and health so that governmental interference is expected to minimize the adverse effects that might arise from the practice of prostitution. This practice is different from that in Indonesia. It adheres to the Eastern culture which states that prostitution is a wrong profession because it degrades women's honour and dignity [5].

Working to earn a living is a right recognized by the state; carrying out religious orders is also another right which also includes rights guaranteed by the government. Some people believe that sexual service providers or prostitution are jobs that can financially support them and their families. However, on the other hand, there are also many parties who object to the existence of the profession because of its negative impact. Western countries protect all forms of work carried out by everyone, without considering the profession in terms of morality [6].

It can henceforth be unveiled the differing views of the Eastern countries in responding to prostitution. Western countries tend to put forward the phrase "prostitution is not a crime" rather than the expression "prostitution is a real crime". In Western countries, sex service providers are protected by law and can freely practice their services in places provided by the government. The health of sex workers is monitored regularly, and sanitation is sought. Such a concept will be used as a theory of thought for the formation of several laws and regulations that do not consider the importance of preventing prostitution in the community, some of which tend to facilitate rather than limit their development [7]

Human rights in Indonesia are also regulated in Law No. 39 of 1999, in Article 20 concerning freedom of person, it is explained that "Slavery or serfdom, the slave trade, trafficking of women, and all other acts of similar purpose are prohibited" [8]. According to this rule, one can underline that providing commercial sex services, users and commercial sex workers is prohibited because prostitution is a form of exploitation of women.

Article 296 of the criminal law states that "Anyone who intentionally connects or facilitates obscene conduct by another person with another person, and makes it a search or habit, is threatened with imprisonment of at most one year and four months or a fine of at most one thousand rupiahs ". As for article 506, it is stated that" Whoever benefits from the obscene conduct of a woman and makes it as a search, is threatened with a maximum sentence of one-year imprisonment ". From the article as mentioned earlier, we can know that the threat of criminal penalties is only to those who provide or facilitate or who benefit from the commercial sex businesses.

The rule of law does not apply stagnantly but there is always dynamics and development because the actual rules were made to protect human rights and not to limit precise movements or actions. If a legal regulation does not bring benefit, a review upon it is then necessary. Apart from criminal law on prostitution, Indonesia also regulates laws on information and technology transactions, in article 27 paragraph 1 no. 11 of 2008 it is stated that "Everyone who intentionally and without rights distributes and/or transmits and/or makes access to electronic information and/or electronic documents that have a charge of violating decency is punishable by imprisonment for a maximum of 6 (six) years and/or a fine of at most one billion rupiah".

The number of laws that regulate the problem of prostitution in Indonesia, both offline and online, shows that prostitution is a symptom of the public disease that must be avoided. Let alone Indonesia is a country which adheres to Eastern customs and culture. Problems arising from prostitution include education, social aspects, religious aspects and health aspects [9] in terms of education, prostitution is of demoralization, in terms of the social aspect, prostitution is considered cancer for the community, in terms of religion, it is a despicable act, and in terms of health, prostitution can endanger offspring [10].

The prostitution mentioned in the law has not yet led to legal certainty, because differences of opinion about whether prostitution or commercial sex can be called a profession or not. If prostitution is recognized as a legal profession, the government has the right to protect this profession because it is a livelihood for some people, whereas if prostitution or commercial sex is not a legal profession and is a criminal offence, the government must enforce criminal law against the practice of prostitution. The human rights adopted by Western and Eastern countries appear to be different. In some Western countries, it is protected as a legal profession while in some Eastern countries, it is not a legal profession and considered a symptom of social disease [11].

Indonesia is a country that is predominantly Muslim, Indonesia has Pancasila as its ideology consisting of 5 parts [12]. The first precept states "the Oneness of God," asserting its strong belief in religion. The Indonesians accordingly uphold the values taught by religion and is reflected in their behaviour and actions. Prostitution is 
something that strongly opposes religious values, the practice of selling oneself is very contrary to the position of Indonesian citizens who grow up with strong religious values so that prostitution is considered a crime against morality and is against the law. Prostitution is henceforth a disgraceful act.

The fifth precept of Pancasila states "Social justice for all Indonesian people". It implies that every Indonesian get fair treatment in all the legal, political, social, economic and cultural fields. Following the 1945 constitution, social justice also includes the concept of justice and prosperity. Social justice is not that signified by the socialist or communalist notion, because what is meant by social justice in the 5th Precepts is inseparable relation between individuals and society. Society is for the sake of life and personal development, while individuals are component of society [13].

It is argued that articles 296 and 506 of the criminal law comprehends only providers of commercial sex services while users of sex services and sex workers are not charged with punishment. If so, the practice of prostitution cannot be eradicated or eliminated, due to the absence of a law against the customers of commercial sex services and commercial sex workers.

According to the information and technology transaction laws, one could be charged with criminal law if he or she intentionally spread content that is considered to violate decency and other people can access the content, this is by article 27 paragraph 1 no 11 concerning ITE. In this case, it can entangle the practice of online prostitution in Indonesia. In the previous criminal law which only ensnared one party; the provider of commercial sex services, the ITE law could ensnare both parties; providers of commercial sex services and commercial sex workers, but there were third parties who had not been caught in criminal sanctions; the users or customers [14].

The Information and Electronic Transaction Law have thus neither provided social justice for all Indonesian people. Because if a third party; a user of commercial sex services is not charged, the practice of prostitution will still linger in the community.

The desired justice in the context of prostitution is that the three parties consisting of providers, service users and commercial sex workers be entangled with criminal sanctions. If some regulations or laws ensnare the three parties, then this is by the concept of human rights which must obtain full justice and be protected by the government [15].

\section{Conclusions}

The practice of prostitution in Indonesia violates the state ideology of Pancasila. It contradicts the first principle that spells out "the Oneness of God" which means prostitution is considered a despicable act of any religion. Moreover, it negatively affects education, social and religion. In the fifth precept, which states "Justice for all Indonesian people" the criminal sanctions against prostitution is not by the concept of full justice for the community in legal matters.

In the concept of human rights requires equal rights obtained by every person both in social, religious, legal, political and other matters. If the threat of criminal sanctions only ensnares one party, not all parties involved in prostitution, then the applicable law is not by human rights law, where all the rights of each person are the same and protected.

This research suggests the idea of adding word content in criminal law laws 296 and 506 and the Electronic Information and Transaction law article 27 paragraph 1 no. 11 of 2008, namely service users and commercial sex workers are threatened with criminal sanctions. Thus all components of the practice of prostitution in Indonesia are trapped by criminal law, and this is considered fair according to human rights.

\section{References}

[1] A. M. Pradana, “Tinjauan Hukum Pidana Terhadap Prostitusi Dan Pertanggungjawaban Pidana Para Pihak Yang Terlibat Dalam Prostitusi,” J. Huk. Pembang., 2016.

[2] J. Kenedi, "Prostitusi Dalam Perspektif Hak Asasi Manusia Dan Islam (Studi Kasus Praktek Prostitusi Di Kota Bengkulu)," J. Ilm. Mizani Wacana Hukum, Ekon. Dan Keagamaan, Vol. 4, No. 1, Pp. $1-8,2018$.

[3] S. P. Rahmat, "Penelitian Kualitatif," Penelit. Kualitatif, 2009.

[4] International Law Making, "Dekiarasi Universal Hak-Hak Asasi Manusia," Indones. J. Int. Law, 2006.

[5] B. Hermanto, "Penanganan Patologi Sosial Dalam Perspektif Sosiologi Hukum Islam (Studi Kasus Penutupan Lokalisasi Teleju Oleh Pemko Pekanbaru),” Kutubkhanah, 2011. 
[6] D. F. Sari And M. F. Maruf, "Proses Pemberdayaan Bagi Warga Terdampak Penutupan Lokalisasi Dolly Di Kelurahan Putat Jaya Kecamatan Sawahan Surabaya,” Publika, 2016.

[7] M.-L. Skilbrei And C. Holmström, "Is There A Nordic Prostitution Regime?," Crime And Justice, 2011.

[8] Presiden Ri., "Undang-Undang Ri. Nomor 39 Tahun 1999 Tentang Hak Asasi Manusia," Menteri Negara Sekretaris Negara Republik Indonesia. 1999.

[9] A. Sitepu, "Dampak Lokalisasi Prostitusi Terhadap Perilaku Remaja Di Sekitarnya," Pemberdaya. Komunitas, 2004.

[10] M. H. Ditmore, "Encyclopedia Of Prostitution And Sex Work, Volumes 1 \& 2," Soc. Sci., 2006.

[11] M. Farley, I. Baral, M. Kiremire, And U. Sezgin, "Prostitution In Five Countries: Violence And Post-Traumatic Stress Disorder," Fem. Psychol., 1998.

[12] E. A. Meinarno, "Pancasila," In Buku Ajar 3 Bangsa, Negara, Dan Pancasila, 2015.

[13] A. Aminullah, "Inplementasi Nilai-Nilai Pancasiladalam Kehidupan Bermasyarakat," J. Ilm. Ikip Mataram, 2016.

[14] H. Herman, "Pengaturan Dan Sistem Penyelesaian Tindak Pidana Prostitusi Online Menurut Hukum Positif," Jurisprud. Jur. Ilmu Huk. Fak. Syariah Dan Huk., 2019.

[15] S. R. Juita, A. Triwati, And A. S. Abib, "Reformulasi Pertanggungjawaban Pidana Pada Pelaku Prostitusi Online: Suatu Kajian Normatif," J. Din. Sos. Budaya, 2018. 